\title{
An Analysis of Competitiveness of Pakistan's Agricultural Export Commodities
}

\author{
Muhammad Rizwan-ul-Hassan \\ Department of Business Administration Mohammad Ali Jinnah University, Karachi
}

\begin{abstract}
This paper analyzes the global competitiveness of Pakistan's agricultural exports, rice, fish and fish preparations, vegetables and fruits, meat and meat preparations, vis-a-vis major Asian competitors using the approach of revealed comparative advantage (RCA), during the period 2001-2010. The results indicate that rice exhibits very strong comparative advantage while increasing trend has been observed in all other commodities reflecting heavy potentials for export growth in global market. There is a need for Pakistan to strengthen the competitiveness in all these sectors.
\end{abstract}

Keywords:Agricultural commodities, Competitiveness, Revealed Comparative advantage

Submitted Date 20 June 2013

Accepted Date: 25 June 2013

\section{Introduction}

World has witnessed significant transformation in composition and structure of trade inlast two decades which has been the result of accelerated trade liberalization process, advancement in technology, stringent foreign trade rules and regulations and concrete outward oriented policies of many economies ${ }^{1}$. Consequently many countries of South America and Asia exploited their potentials of comparative advantages and enjoyed sustained growth in foreign trade, providing employment and rising income of their citizens.

Pakistan is blessed with diverse agro-climatic conditions, which are conducive to growing various crops, almost all the year and one of the best irrigation systems in the world.(Akhter-1999)[1].Pakistan exhibits strong comparative advantage in a number of agricultural commodities or commodities groups, like rice, fish and fish preparations, fruits and vegetables and so much so that getting competition in global export market of meat and meat preparations. But rapidly changing international trade scenario led by WTO rules and regulations, competition in international market is getting more intensified specially with the emergence of new foreign trade players like Vietnam and Thailand. As Mustafa(2003)[2] has pointed out that, the ability of the country to maintain or expand its world market share depends upon its ability to meet the demands of the world trading system, not only in terms of competitive price but also quality of exportable products and their safety standards. As Pakistanis the signatory of WTO, Agreement on Agriculture it has to restructure its foreign trade policies.

Pakistan government has realized this fact and announced that, "Enhancing export competitiveness of Pakistan would largely depend upon the quality of governance and management structures deployed to implement it. Ministry of commerce has planned broad based structural trade reforms(Ministry of Commerce$2009)^{2 \%}$. This paper is an attempt to analyze the comparative advantage of a number of agricultural commodities relative to leading competitors in Asia. This comprehensive analysis is helpful in identifying strength and weaknesses of agricultural commodities of Pakistan and assist trading policy makers in redesigning their strategies.

The plan of the paper is as follows, section 2 reviews the literature while section 3highlights the data access and methodology. Section 4 examines RCA indices of major export agricultural commodities of Pakistan with leading competitors of Asia. Last section concludes the paper.

\section{Literature Review}

RCA indices have been widely used to assess comparative advantage of export commodities in various studies for last three decades.

\footnotetext{
${ }^{1}$ Batra\& Khan (2005), Burrange\&Chaddha (2008), Ghani (2008), Mehmood (2004)

*Author is Assistant Professor at Muhammad Ali Jinnah University, Karachi Campus. E-mail: rizwanulhassan250@hotmail.com

Note: Author is highly thankful to Dr. Khalid Mustafa, Assistant Professor Department of Economics, University of Karachi, for his valuable comments on the early draft of this paper.

${ }^{2}$ Strategic Trade Policy Frame work 2009-2012, presented by Minister of Commerce Mr. Makhdoom Amin Fahim, available as official document in the office of ministry of commerce indicating various trade reforms to promote exports.
} 
Richardson and Zhang (1999)[3] measured trade performance of USA in 1980 and 1995 using Balassa $\mathrm{RCA}^{3}$ index with 38 of its large trading partners including EU 15,NAFTA, China and Japan. They included broad commodity classification under SITC from SITC 1 of primary products to SITC 8 of finishedmanufactures. They found that US comparative advantage did not change much between 1980 and 1995 when measured worldwide on single digit product classification. When these worldwide patterns were broken to calculate RCA across regional trading partners,the aggregates were not homogenous. The results indicated different trade patterns across different parts of the world,over time and for different levels of aggregates.

Ferto and Hubbard (2003)[4] used Balassa RCA index to examine relative competitiveness of Hungary's trade in agricultural and food products vis-à-vis the EU for a period from 1992-1998. They concluded that comparative advantage was observed in eleven out of 22aggregated product groups and results complemented the previous studies using price and cost-based methods. But they also warned that due to the chances of government intervention results needed to be interpreted with care.

Mahmood (2004)[5] analyzed export competiveness and comparative advantage of Pakistan's nonagricultural 25 commodities by using Balassa RCA index. He divided these commodities in four categories, competitive positioned products, threatened positioned products, emerging product and weakly positioned products on the basis of RCA index. He concluded that Pakistan's non-agricultural sector witnessed competitive positioning of some of its sectors but these trends were not uniform across all sectors. Secondly Pakistan has failed to move from low value- added unskilled labor intensive to technology -intensive high- value added manufacturing.

Comparative advantages was measured by Batra and Khan (2005) for commodities groups sectors in 97 chapters of HS- 1996 using RCA index for both India and China for 2000 and 2003.

The analysis revealed thatthe pattern of comparative advantage varied at different levels of commodity disaggregation.Sectors that ranked among the top ten according to the value of the index ofRCA were not necessarily able to retain their position when ranked according tocomparative advantage at the 6 digit constituent commodity level. In the case of India,otherthan cotton, no other sector could retain its comparative ranking at the dis-aggregated level. Simultaneously, there were also somesectors where either of the countries may bedisadvantageously placed at the aggregatelevel but may enjoy comparative advantage at the constituent commodity level.

Burrange and Chaddha(2008)[7] made assessment of India s' revealed comparative advantage in exports over a period of 10 years from 1996 to 2005.Commodities were selected of various sectors according to $\mathrm{H}-\mathrm{S}$ classification at 2-digit and 6 digit level. The study concluded that labor- intensive chapters of textiles and scale-intensive chapters of iron and chemicals were the foremost chapters enjoying a comparative advantage in India. The RCA index for goods required advanced technology was less than unity throughout the study period.

Ghaniet al. (2008)[8] used Balassa RCA index to measure revealed comparative advantage for footwear industry in Pakistan. The analysis was divided at 2-digit and 4-digit HS classification for the time period from 1996 to 2006 and then compared with footwear industry of China and India. The study concluded that at two- digit level Pakistan footwear industry shifted into comparative advantage since 2003 and RCA index has been increasing continuously over the years while comparative advantage of China and India declined since 2001.At four- digit level Pakistan experienced strong growth in three products at disaggregated level.

Shahet al. (2009)[9] examined competitiveness of selected Pakistani fruits with major global fruit exporters by using Balassa RCA and other RCA indices for a period from 1995-2005.The study arrived at a conclusion that Pakistan has a higher comparative advantage in dates and mangoes relative to its main competitors while Pakistan has lowest comparative advantage in relative to major exporters in oranges except USA.

\section{Data and Methodology}

To analyze the competitiveness of Pakistan's agricultural exports four commodities groups were selected, rice, fish and fish preparations, fruits and vegetables, meat and meat preparations. Selection is based on their collective export share in total export share of Pakistan which is $16.5 \%$ in 2008(UNCOMTRADE) ${ }^{4}$.Secondly so far no study has been conducted to analyze export performance of commodities like fruit and vegetables as well as meat and meat preparations of Pakistan although these

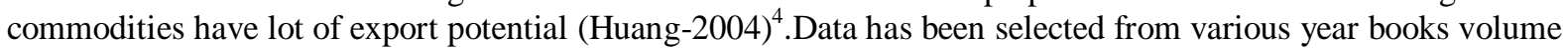
I and II of UNCOMTRADE (United Nations Commodity Trade Statistics Data Base, Statistics Division) for a period from 2001 to 2010, based onSITC Rev-3 classification. Data has also been acquired for the same period

\footnotetext{
${ }^{3}$ BelaBalassa in 1965 presented a new concept of revealed comparative advantage calculated as RCA index.

${ }^{4}$ Huang, S.W.(2004),Global Trade Patterns in Fruits and Vegetables. United States, Department of Agriculture. Available on http: //www.ers.usda.gov.
} 
of respective commodities groups of leading competitors of Asia. Competitors exist outside Asia were excluded on the basis of low geographic proximity.

The current world trade is highly influenced by enormous market distortions, and data on which is difficult to generate, that is why the approach of comparative advantage presented by David Ricardo (1817)[10] could not be applied for the measurement of trade performance.

To overcome this difficulty,Bela-Balassa (1965)[11] presented a new approach of "revealed comparative advantage", realizing the issue of non-availability and accuracy of data on foreign trade market distortions. As he described in his paper, "But is it necessary to explicitly take account of all influences that determine comparative advantages? This would be a rather laborious exercise and, in view of the difficulties of assigning values to these variables, it might bring disappointing results. Instead, for the purpose of indicating the possible consequences of trade liberation, it appears sufficient to provide information on,"revealed" comparative advantages."

The RCA index, presented by Balassa, is in the shape of ratios of two shares. The numerator is the share of country export of a particular commodity in its total world export. The denominator is the share of world's export of that commodity in total world export. The commodity indicates revealed comparative advantage if value exceeds unity and vice versa.

The standard Balassa s' RCA index is in following form:

$$
R C A=\frac{X_{i j t} / \sum X_{j t}}{\sum X_{i w t} / \sum X_{w t}}
$$

Where, $X_{i j t}=$ Exports of commodity " $i$ " from country " $j$ " at given time " $t$ ".

$X_{j}=$ Total exports of country " $j$ " at given time " $t$ ".

$X_{i w t}=$ World's exports of commodity " $i$ " at given time " $t$ ".

$X_{w t}=$ Total world exports at given time " $t$ ".

The advantage of using RCA index is that it considers the intrinsic advantage of a particular export commodity and is consistent with the change in an economy s' relative factor endowment and productivity. The disadvantage however, is that it cannot distinguish improvements in factor endowment and pursuit of appropriate trade policies by a country (Batra and Khan, 2005).Hinloopin and Van Marrewiyk (2001)[12] did extensive work on RCA index and divided into four classes.

Class a: $0<\mathrm{RCA}$ index $\leq 1$

Class b: $1<$ RCA index $\leq 2$

Class c: $2<$ RCA index $\leq 4$

Class d:4< RCA index

Class "a" refers to those product groups without a comparative advantage. The other three classes, b,c, and d describe sectors with a comparative advantage roughly classified into weak comparative advantage, (class b), medium comparative advantage (class c) and strong comparative advantage (class d).

\section{Result and Discussion}

Commodities group wise detail of the results is presented in this section.

4.1Rice: The RCA indices of Pakistan and its major Asian competitors, India, Thailand and Vietnam have been presented in Table-1. Pakistan exhibits very strong comparative advantage over the whole period under investigation relative to its competitors. It is not only consistent but improving as RCA index 47.71 in 2001(RCA>47) and improved substantially in 2010 touching the mark of 78 (RCA>78). on the contrary Indian comparative advantage is declining as it is RCA index $=13.2$ in 2001 while deterioted to RCA index $=7.66$ in 2010 indicated in table-1.

Table-1: RCA index - Rice - SITC Rev-3, Code-04

\begin{tabular}{|l|l|l|l|l|}
\hline & Pakistan & Thailand & Vietnam & India \\
\hline $\mathbf{2 0 0 1}$ & 47.7 & 20.53 & 35.12 & 13.27 \\
\hline $\mathbf{2 0 0 2}$ & 43.24 & 22.15 & 40.23 & 21.33 \\
\hline $\mathbf{2 0 0 3}$ & 49.20 & 22.55 & 35.32 & 14.05 \\
\hline $\mathbf{2 0 0 4}$ & 50.39 & 27.67 & 35.50 & 17.48 \\
\hline $\mathbf{2 0 0 5}$ & 70.51 & 21.72 & 44.69 & 16.80 \\
\hline $\mathbf{2 0 0 6}$ & 77.15 & 22.44 & 36.37 & 13.64 \\
\hline $\mathbf{2 0 0 7}$ & 67.47 & 23.77 & 32.12 & 16.87 \\
\hline $\mathbf{2 0 0 8}$ & 91.06 & 26.21 & 34.87 & 11.80 \\
\hline $\mathbf{2 0 0 9}$ & 65.58 & 21.87 & 30.31 & 8.80 \\
\hline $\mathbf{2 0 1 0}$ & 78.74 & 20.13 & 33.38 & 7.66 \\
\hline
\end{tabular}

Source: Data collected from Year books of UNCOMTRADE, United Nations Statistical Division, computation made by author. 
On the other hand both Thailand and Vietnam also exhibit strong comparative advantage which is consistent through the period under investigation indicating that for Thailand (RCA $>20)$ and for Vietnam $(\mathrm{RCA}>30)$.

4.2Fish and Fish Preparations: This commodity group includes fish, shrimps and crustacean comes under main SITC heading 03. Table-2 shows the RCA indices of this group. Pakistan remained greater than one (RCA>1)throughout the period under investigation. Among competitors China exhibits similar level of comparative advantage to that of Pakistan but Thailand and Vietnam posed sever competition to Pakistan as RCA index for Thailand is higher(RCA index $>20$ ) through the period, while RCA index of Vietnam remained more then 10(RCA $>10)$ during the whole period of study indicating that Vietnam holds very strong position for the export of fish and fish preparation in international market. But another fact is that for both Thailand and Vietnam RCA index is gradually falling which is not the case of Pakistan.

Table-2:RCA index - Fish and Fish Preparations - SITC Rev-3, Code-03

\begin{tabular}{|l|l|l|l|l|}
\hline & Pakistan & China & Thailand & Vietnam \\
\hline $\mathbf{2 0 0 1}$ & 1.57 & 1.69 & 7.01 & 13.5 \\
\hline $\mathbf{2 0 0 2}$ & 1.42 & 1.59 & 6.22 & 14.12 \\
\hline $\mathbf{2 0 0 3}$ & 1.52 & 1.44 & 5.85 & 18.14 \\
\hline $\mathbf{2 0 0 4}$ & 1.47 & 1.54 & 5.78 & 11.85 \\
\hline $\mathbf{2 0 0 5}$ & 1.61 & 1.42 & 5.83 & 12.25 \\
\hline $\mathbf{2 0 0 6}$ & 1.72 & 1.39 & 5.98 & 12.70 \\
\hline $\mathbf{2 0 0 7}$ & 1.65 & 1.22 & 5.89 & 12.54 \\
\hline $\mathbf{2 0 0 8}$ & 1.98 & 1.21 & 6.31 & 12.35 \\
\hline $\mathbf{2 0 0 9}$ & 1.75 & 1.19 & 5.7 & 10.43 \\
\hline $\mathbf{2 0 1 0}$ & 1.79 & 1.23 & 5.27 & 10.25 \\
\hline
\end{tabular}

Source:Data collected from Year books of UNCOMTRADE, United Nations Statistical Division, computation made by author.

4.3 Vegetables and Fruits:Asia takes around 44\% of world's' acreage of fruit production, but export of fruit from Asia lags behind those from other major fruit producing regions such as central America which takes 33\% share of global fruit export and South America with 37\% share. (APCAEM-2006)

RCA indices for vegetables and fruits have been shown of leading Asian exporters including Pakistan in Table-3.Pakistan possesses a weak competitive position in global vegetables and fruits market as RCA index is closed to one in whole of the period under investigation and in the years 2002, 2006 and 2008 it is less than one (RCA <1). Out of the whole group of vegetables and fruits, a study (Akhter, Sharif and Shah, 2009) has been carried out for selected Pakistani fruits(dates, mangoes and oranges) indicated that Pakistan has strong comparative and competitive advantage in these fruits.

Table-3 indicates that other major exporters of vegetables and fruits of Asia, like China, Thailand and India, do not hold strong comparative advantage over Pakistan as they exhibit RCA=1.

Looking at competitors, Pakistan can easily penetrate in global market of vegetables and fruits. The Middle East countries and Gulf States are important markets for Pakistani vegetables and a fruit because these markets are still expanding very rapidly and Pakistan has lot of potentials to increase the export of vegetables and fruits in these countries. (Akhter-1998)[13]

Table-3: RCA index - Vegetables and Fruits - SITC Rev-3, Code-05

\begin{tabular}{|l|l|l|l|l|}
\hline & Pakistan & China & Thailand & India \\
\hline $\mathbf{2 0 0 1}$ & 1.01 & 1.32 & 1.69 & 1.66 \\
\hline $\mathbf{2 0 0 2}$ & 0.95 & 1.14 & 1.64 & 1.49 \\
\hline $\mathbf{2 0 0 3}$ & 1.07 & 1.06 & 1.69 & 1.35 \\
\hline $\mathbf{2 0 0 4}$ & 1.04 & 0.99 & 1.81 & 1.40 \\
\hline $\mathbf{2 0 0 5}$ & 1.30 & 0.94 & 1.70 & 1.52 \\
\hline $\mathbf{2 0 0 6}$ & 0.97 & 0.94 & 1.78 & 1.41 \\
\hline $\mathbf{2 0 0 7}$ & 1.11 & 0.93 & 1.66 & 1.18 \\
\hline $\mathbf{2 0 0 8}$ & 0.97 & 0.88 & 1.60 & 1.17 \\
\hline $\mathbf{2 0 0 9}$ & 1.34 & 0.83 & 1.54 & 0.97 \\
\hline $\mathbf{2 0 1 0}$ & 1.57 & 0.91 & 1.51 & 0.95 \\
\hline
\end{tabular}

Source:Data collected from Year books of UNCOMTRADE, United Nations Statistical Division, computation made by author.

\footnotetext{
5 APCAEM (2006), United Nations Economic and Social Commission for Asia and Pacific
} 
4.4Meat and Meat Preparations:Table-4 shows RCA index of Pakistan and its competitors for meat and meat preparations. Pakistan exhibits a weak position $($ RCAindex $<1$ ) throughout the period under investigation, but important fact is that trend seemed to be increasing as RCA index $=0.09$ in 2002 but in 2010 RCA index $=0.77$. which reflects its potentials. On the other hand there is no major competitor in Asia in the field of meat and meat preparations export. India has been found to have RCA index $<1$ except 2010 when it touched the mark of RCA index 1.11.In terms of RCA index China also displays a weak position RCA index $<1$ throughout the period under study. The comparative advantage has been consistent for Thailand from 2001 to 2010 posing competitive pressure to Pakistan.

The sector has lot of potential for Pakistan as realized by the government, livestock sector accounts for 11.3\% of Pakistan s' GDP but the livestock based exports are negligible. (Ministry of Commerce Pakistan-2009)

Table-4: RCA index - Meat and Meat Preparations- SITC Rev-3, Code-01;

\begin{tabular}{|l|l|l|l|l|}
\hline & Pakistan & China & India & Thailand \\
\hline $\mathbf{2 0 0 1}$ & N/A & 0.69 & 0.71 & 1.91 \\
\hline $\mathbf{2 0 0 2}$ & 0.09 & 0.54 & 0.69 & 2.21 \\
\hline $\mathbf{2 0 0 3}$ & 0.18 & 0.43 & 0.78 & 1.96 \\
\hline $\mathbf{2 0 0 4}$ & 0.24 & 0.38 & 0.66 & 1.01 \\
\hline $\mathbf{2 0 0 5}$ & 0.20 & 0.34 & 0.86 & 1.15 \\
\hline $\mathbf{2 0 0 6}$ & 0.27 & 0.31 & 0.91 & 1.18 \\
\hline $\mathbf{2 0 0 7}$ & 0.39 & 0.25 & 0.87 & 1.21 \\
\hline $\mathbf{2 0 0 8}$ & 0.42 & 0.18 & 0.92 & 1.49 \\
\hline $\mathbf{2 0 0 9}$ & 0.55 & 0.19 & 0.81 & 1.37 \\
\hline $\mathbf{2 0 1 0}$ & 0.77 & 0.21 & 1.11 & 1.34 \\
\hline
\end{tabular}

Source:Data collected from Year books of UNCOMTRADE, United Nations Statistical Division, computation made by author.

Note: For Pakistan Data collected from UNCOMTRADE for 2006 -2010 and from remaining period collected from State Bank of Pakistan as UNCOMTRADE does not include data for any exportcommodity having trade value less than $5 \%$ of total export volume of that country.

\section{Conclusion}

We have presented an analysis of competitiveness of Pakistan's agricultural export commodities in relation to leading Asian competitors on the basis of Balassa revealed comparative advantage for the period 2001 -2010.The estimated results indicate an upward trend in competitiveness of all export commodities bur these results are on the basis of post trade data which are influenced by market distortions, nevertheless they provide an idea of agricultural export trend.

Rice is an important agricultural export facing increasing pressure from Thailand and Vietnam, requiring restructuring of macroeconomic policies at the level of cultivation, processing and marketing .RCA index has been consistent for the sector fish and fish preparations. Though the sector has lot of potential but confronting the challenge of high cost and low yield, over fishing, sanitary and phytosanitary issues.

Vegetables and fruits, meat and meat preparations are relatively new sectors for Pakistan. Movement of RCA indices towards improvement in exports reflecting their potentials, but there is a need to overcome supply side constraints. Better management at the levels of production, processing, packing and storage is very essential. It requires investment friendly policies, encouragement of technology transfer and vigorous training at human resource level.

In the rapidly developing scenario of trade liberalization and strict trade rules and regulations, Pakistan needs to develop efficient system to redesign and review its trade policies.

\section{References}

[1] Akhter, M.R., Effects of Trade Liberalization on Agriculture in Pakistan: Commodity Aspects. Working Paper 44/1999 the CGPRT Centre, Bogor Indonesia.

[2] Mustafa, K., BarriersAgainst Agricultural Export from Pakistan: the role of WTO Sanitary and Phytosanitary Agreement. Pakistan Development Review, Volume 42, (4),2003 part II.

[3] Richardson,D.J.and C. Zhang, Revealing Comparative Advantage :Chaotic or Coherent Patterns Across Time and Sectors and U.S. Trading Partners? National Bureau of Economic Research. Working Paper No.7212/1999

[4] Ferto,I and L.J. Hubbard, Revealed Comparative Advantage and Competitiveness in Hungarian Agri-Food Sectors. The World Economy. Volume 26, (2),2003, 247-259.

[5] Mahmood, A., Export Competitiveness and Comparative Advantage of Pakistan s' Non-agricultural Production Sector: Trends and Analysis, Pakistan Development Review, Volume 43(4) Part II, 2004, 541-561.

[6] Batra, A and Z.Khan, Revealed Comparative Advantage: An analysis for India and China. ICRIER Working Paper No 168.2005, New Delhi.

[7] Burrange, L.G.and S.J.Chaddha, India s' Revealed Comparative Advantage in Merchandise Trade Working Paper UDE 28/6/2008. Department of Economics, University of Mumbai. 
[8] Ghani, E.,N. Zakir and N.Akhter,Changing Revealed Comparative Advantage: A case study of Foot Wear Industry in Pakistan.Pakistan Development Review. Volume 47,(4),2008, 695-709.

[9] Shah,H., M. Sharif, and W. Akhter, Competitiveness of Pakistani Fruits in the World Market. The Lahore Journal of Economics, Volume14, (2),2009, 125-133

[10] Ricardo, D., On the principles of political economy and taxation .Publisher John Murray, Albemarle Street, London.1817

[11] Balassa, B., Trade Liberalization and Revealed Comparative Advantage. The Manchester School of Economics and Social Studies, $33,1965,92-123$.

[12] Hinloopen,J andC.VanMarrewijk, On the Empirical Distribution of Balassa Index.Review of World Economics, Volume137 (1),2001, $1-35$.

[13] Akhter, M.R. , Effects of Trade Liberalization on Agriculture in Pakistan: Institutional and Structural Aspects. Working Paper 33/1998, the CGPRT Centre, Bogor Indonesia. 